6. Salkeld DJ, Nieto NC, Carbajales-Dale P, Carbajales-Dale M, Cinkovich SS, Lambin EF. Disease risk and landscape attributes of tick-borne Borrelia pathogens in the San Francisco Bay area, California. PLoS ONE. 2015;10:e0134812. http://dx.doi.org/10.1371/ journal.pone. 0134812

7. Barbour AG. Phylogeny of a relapsing fever Borrelia species transmitted by the hard tick Ixodes scapularis. Infect Genet Evol. 2014;27:551-8. http://dx.doi.org/10.1016/j.meegid.2014.04.022

8. Barbour AG, Maupin GO, Teltow GJ, Carter CJ, Piesman J. Identification of an uncultivable Borrelia species in the hard tick Amblyomma americanum: possible agent of a Lyme disease-like illness. J Infect Dis. 1996;173:403-9. http://dx.doi.org/10.1093/ infdis/173.2.403

9. Bunikis J, Tsao J, Garpmo U, Berglund J, Fish D, Barbour AG. Typing of Borrelia relapsing fever group strains. Emerg Infect Dis. 2004;10:1661-4. http://dx.doi.org/10.3201/eid1009.040236

10. Margos G, Gatewood AG, Aanensen DM, Hanincova K, Terekhova D, Vollmer SA, et al. MLST of housekeeping genes captures geographic population structure and suggests a European origin of Borrelia burgdorferi. Proc Natl Acad Sci U S A. 2008;105:8730-5. http://dx.doi.org/10.1073/pnas.0800323105

Address for correspondence: Alan G. Barbour, Department of Microbiology and Molecular Genetics, University of California Irvine, 843 Health Sciences Rd., Irvine, CA 92697-4028, USA; email: abarbour@uci.edu

\section{Xenopsylla brasiliensis Fleas in Plague Focus Areas, Madagascar}

\section{Adélaïde Miarinjara, Christophe Rogier, Mireille Harimalala, Tojo R. Ramihangihajason, Sébastien Boyer}

Author affiliations: Université d'Antananarivo, Antananarivo, Madagascar (A. Miarinjara); Institut Pasteur, Antananarivo (A. Miarinjara, C. Rogier, M. Harimalala, T.R. Ramihangihajason, S. Boyer);

\section{DOI: http://dx.doi.org/10.3201/eid2212.160318}

To the Editor: Plague is a life-threatening infectious disease caused by the gram-negative bacterium Yersinia pestis (1). Y. pestis primarily infects rodents but can also cause outbreaks of plague in humans. The infection is usually transmitted within murine populations and then to humans by bites from infected fleas. The oriental rat flea, Xenopsylla cheopis, is considered the most efficient plague vector (1). Plague remains a major public health threat, causing annual epidemics, especially in Madagascar.

From November 2013 through January 2014, Madagascar reported 427 suspected cases and 45 confirmed cases of plague (both bubonic and pneumonic) in 4 districts. We report here on the flea species associated with rodents and those collected from human dwellings in the Mandritsara District where plague occurred (online Technical Appendix Figure, http://wwwnc.cdc.gov/EID/ article/22/10/16-0318-Techapp1.pdf). Four villages in the district were investigated 1 month after the end of the human plague epidemic and after an insecticide-based vector control intervention had taken place. Fleas were collected, either from rats or by using candle traps set inside houses, and preserved in 70\% ethanol (online Technical Appendix Table). Rats were trapped alive inside houses and in the cultivated lands.

During the survey, 180 rodents were trapped; they belonged to species Rattus rattus $(93.3 \%, \mathrm{n}=168)$, Mus musculus $(5.6 \%, \mathrm{n}=10)$, and Suncus murinus $(1.1 \%, \mathrm{n}=$ 2). A total of 50 fleas were collected from these rodents. The fleas belonged to 4 species: Sinopsyllus fonquerniei $(\mathrm{n}=26)$, Xenopsylla brasiliensis $(\mathrm{n}=14), X$. cheopis $(\mathrm{n}$ $=9)$, and Echidnophaga gallinacea $(\mathrm{n}=1)$ (Table). The first 3 are known to be $Y$. pestis vectors. Of fleas caught in candle traps placed inside houses, $\approx 98 \%$ were the human flea Pulex irritans, whose role in plague outbreaks is unknown $(2,3)$.

Although $X$. cheopis and $S$. fonquerniei fleas are common $Y$. pestis vectors in Madagascar (1), the major finding of this study was the discovery of $X$. brasiliensis fleas, which may be involved in plague transmission in Madagascar. Fleas were identified to the species under binocular magnification by using systematic keys $(4,5)$. Each flea specimen was identified independently by 2 different technicians. The morphologic identification of $X$. brasiliensis (Baker, 1904) was also confirmed by Jean-Claude Beaucournu (6). Specimens of $X$. brasiliensis fleas identified in this study exhibit the morphologic characteristics of the species, which distinguish it from $X$. cheopis fleas, as follows: antepygidial bristle of male is marginal, inserted on the long pedestal, process 1 of the clasper with 8 or 9 bristles (which are stout, straight, spiniform, and 1 angled) and the process 2 of the clasper with the tip turned up (5). Compared with females of other Xenopsylla spp., X. brasiliensis females have a distinct spermathecal shape with a very swollen bulga, which is larger than the base of the hilla (4). Moreover, DNA of $X$. brasiliensis, P. irritans, and X. cheopis fleas collected during this study was extracted and amplified by using primers targeting the D3 segment of the $28 \mathrm{~S}$ ribosomal RNA-encoding gene (7) and sequenced. $X$. brasiliensis sequences isolated showed $100 \%$ nucleotide similarity with those from Mauritius (4) and were different from $X$. cheopis and $P$. irritans sequences. All sequences are available in GenBank (accession nos. KU759935-KU759954). 
Table. Number of fleas collected from rodents and by candle traps per species and per study site, Madagascar, 2013-2014

\begin{tabular}{lccccc}
\hline Source & Flea species & Beranimbo & Ambiamamy & Sahakondro & Antsiatsiaka $^{*}$ \\
\hline Rattus rattus rat & Synopsyllus fonquerniei & 21 & 1 & 4 & 0 \\
& Xenopsylla cheopis & 1 & 0 & 0 & 7 \\
& Xenopsylla brasiliensis & 0 & 0 & 0 & 7 \\
& Echidnophaga gallinacea & 0 & 1 & 3 & 0 \\
\hline Candle trap & Tunga penetrans & 2 & 0 & 0 & 1 \\
& Pulex irritans & 0 & 0 & 0 & 138 \\
& Synopsyllus fonquerniei & 0 & & & \\
\hline${ }^{*}$ Control village where no plague cases and no insecticide treatment occurred. &
\end{tabular}

Given the vital maritime exchange between Madagascar, the countries of East Africa, and the islands of the Indian Ocean, the presence of $X$. brasiliensis fleas in Madagascar was almost predictable. X. brasiliensis fleas originated in sub-Saharan Africa and have spread to other parts of the world, notably Brazil and India (8). This species is among the most common flea species found on rodents in southern and eastern Africa, where it is considered a key $Y$. pestis vector, especially in rural environments (9). This species has been described on the Comoros archipelago and Mauritius since the early 20 th century (5) and, more recently, on Reunion Island (10). However, to our knowledge, X. brasiliensis fleas had not previously been found in Madagascar, although $>40$ species of fleas have been identified in this country since the 1930s. In this study, we found that $X$. brasiliensis fleas were parasitizing $R$. rattus rats caught inside human dwellings. $R$. rattus rats are considered the main plague reservoir in Madagascar (1).

This study's key finding is the discovery of a third vector species that may be involved in $Y$. pestis transmission in Madagascar. Further genetic studies are necessary to clarify when $X$. brasiliensis fleas arrived in Madagascar and where they originated. Additional studies are also needed to determine the distribution of $X$. brasiliensis fleas on the island and their role in plague transmission.

\section{Acknowledgments}

We are grateful to the field team that included agents of the Plague Unit (Institut Pasteur de Madagascar), the Laboratoire Centrale de la Peste (Ministry of Health), and agents of the Unité d'Entomologie Médicale (Institut Pasteur de Madagascar). We also wish to highlight the work of Jean-Claude Beaucournu in the identification and confirmation of $X$. brasiliensis fleas. In addition, we thank Catherine Bourgouin for reading the manuscript.

\section{References}

1. Duplantier J-M, Duchemin J-B, Chanteau S, Carniel E. From the recent lessons of the Malagasy foci towards a global understanding of the factors involved in plague reemergence. Vet Res. 2005;36:437-53. http://dx.doi.org/10.1051/vetres:2005007

2. Leulmi H, Socolovschi C, Laudisoit A, Houemenou G, Davoust B, Bitam I, et al. Detection of Rickettsia felis, Rickettsia typhi, Bartonella species and Yersinia pestis in fleas (Siphonaptera) from Africa. PLoS Negl Trop Dis. 2014;8:e3152. http://dx.doi.org/10.1371/ journal.pntd.0003152

3. Ratovonjato J, Rajerison M, Rahelinirina S, Boyer S. Yersinia pestis in Pulex irritans fleas during plague outbreak, Madagascar. Emerg Infect Dis. 2014;20:1414-5.

4. Duchemin JB. Biogeography of fleas from Madagascar [in French] [doctoral thesis]. Créteil (France): Université de Paris XII Val de Marne; 2003. http://doxa.u-pec.fr/theses/th0212881.pdf

5. Hopkins G, Rothschild M. An illustrated catalogue of the Rothschild collection of fleas (Siphonaptera) in the British Miseums. Cambridge: Cambridge University Press; 1953.

6. Beaucournu JC, Fontenille F. Contribution to a catalogue of fleas from Madagascar (Insecta, Siphonaptera) [in French]. Arch Inst Pasteur Madagascar. 1993; special edition.

7. Koekemoer LL, Lochouarn L, Hunt RH, Coetzee M. Single-strand conformation polymorphism analysis for identification of four members of the Anopheles funestus (Diptera: Culicidae) Group. J Med Entomol. 1999;36:125-30. http://dx.doi.org/10.1093/ jmedent $/ 36.2 .125$

8. Amatre G, Babi N, Enscore RE, Ogen-Odoi A, Atiku LA, Akol A, et al. Flea diversity and infestation prevalence on rodents in a plague-endemic region of Uganda. Am J Trop Med Hyg. 2009;81:718-24. http://dx.doi.org/10.4269/ajtmh.2009.09-0104

9. Gratz NG. Rodent reservoirs and flea vectors of natural foci of plague. In: Plague manual: epidemiology, distribution, surveillance and control; 1999. Geneva: World Health Organization; 1999. http://www.who.int/csr/resources/publications/plague/WHO_CDS CSR_EDC_99_2_EN/en/

10. Guernier V, Lagadec E, LeMinter G, Licciardi S, Balleydier E, Pagès F, et al. Fleas of small mammals on Reunion Island: diversity, distribution and epidemiological consequences. PLoS Negl Trop Dis. 2014;8:e3129. http://dx.doi.org/10.1371/journal.pntd.0003129

Address for correspondence: Adélaïde Miarinjara, Institut pasteur de Madagascar, Unité d'Entomologie Médicale, Institut Pasteur de Madagascar-BP 1274-Antananarivo 101, Madagascar; email: amiarinjara@pasteur.mg 